\title{
Viral replication kinetics and in vitro cytopathogenicity of parental and reassortant strains of bluetongue virus serotype 1, 6 and 8
}

Peter Coetzee ${ }^{1,2 \S}$, Moritz Van Vuuren ${ }^{1}$, Maria Stokstad ${ }^{2}$, Mette Myrmel ${ }^{3}$, René G. P. van Gennip ${ }^{4}$, Piet A. van Rijn ${ }^{4,5}$, and Estelle. H. Venter ${ }^{1}$

${ }^{1}$ Department of Veterinary Tropical Diseases, Faculty of Veterinary Science, University of Pretoria, Private Bag X04, Onderstepoort, Pretoria, 0110, South Africa

${ }^{2}$ Department of Production Animal Clinical Sciences, Norwegian University of Life Sciences , P. O. Box 8146, 0033 Oslo, Norway

${ }^{3}$ Department of Food Safety and Infection Biology, Norwegian University of Life Sciences , P. O. Box 8146, 0033 Oslo, Norway

${ }^{4}$ Department of Virology, Central Veterinary Institute of Wageningen University, P.O. box 65, 8200 AB, Lelystad, The Netherlands

${ }^{5}$ Department of Biochemistry, Centre for Human Metabonomics, North-West University, Private Bag X6001, Potchefstroom, 2520, South Africa

${ }^{\S}$ Corresponding author

Email addresses:

EHV: estelle.venter@up.ac.za

MM: mette.myrmel@nvh.no

MS: maria.stokstad@nvh.no

MvV: moritz.vanvuuren@up.ac.za

P: peter.coetzee@yahoo.com

RvG: rene.vangennip@wur.nl

PvR: piet.vanrijn@wur.nl 


\section{Abstract}

Bluetongue virus (BTV), a segmented dsRNA virus, is the causative agent of bluetongue (BT), an economically important viral haemorrhagic disease of ruminants. Bluetongue virus can exchange its genome segments in mammalian or insect cells that have been co-infected with more than one strain of the virus. This process, may potentially give rise to the generation of novel reassortant strains that may differ from parental strains in regards to their phenotypic characteristics. To investigate the potential effects of reassortment on the virus' phenotype, parental as well as reassortant strains of BTV serotype 1, 6, 8, that were derived from attenuated, and wild type strains by reverse genetics, were studied in vitro for their virus replication kinetics and cytopathogenicity in mammalian (Vero) cell cultures. The results indicate that genetic reassortment can affect viral replication kinetics, the cytopathogenicity and extent/mechanism of cell death in infected cell cultures. In particular, some reassortants of non-virulent vaccine (BTV-1 and BTV-6) and virulent field origin (BTV-8) demonstrate more pronounced cytopathic effects compared to their parental strains. Some reassortant strains in addition replicated to high titres in vitro despite being composed of genome segments from slow and fast replicating parental strains. The latter result may have implications for the level of viraemia in the mammalian host and subsequent uptake and transmission of reassortant strains (and their genome segments) by Culicoides vectors. Increased rates of CPE induction could further suggest a higher virulence for reassortant strains in vivo. Overall, these findings raise questions in regards to the use of modified-live virus (MLV) vaccines and risk of reassortment in the field. To further address these questions, additional experimental infection studies using insects and/or animal models should be conducted, to determine whether these results have significant implications in vivo.

\section{Keywords}

Bluetongue virus, bluetongue, reassortment, cytopathogenicity, replication kinetics, apoptosis, necrosis, modified-live virus vaccine 


\section{Introduction}

Bluetongue virus (BTV) is the prototype of the genus Orbivirus in the family Reoviridae. The virus (26 distinct serotypes) is the causative agent of bluetongue (BT), an economically important disease of wild and domestic ruminants, including sheep, cattle and goats (Spreull, 1905; Verwoerd \& Erasmus, 2004). Bluetongue virus causes injury to the vascular endothelium, resulting in pathophysiological changes including vascular thrombosis, ischaemic necrosis, haemorrhage and vascular leakage (MacLachlan et al., 2009). Acutely affected sheep may show clinical signs including fever, oral and nasal erosions/discharge, oedema (particularly of the face, submandibular region and ears), cyanosis of the tongue, coronitis, respiratory distress, anorexia and death (MacLachlan et al., 2008; Verwoerd \& Erasmus, 2004). Bluetongue virus evolves through a complex process of antigenic drift and shift, coupled with evolutionary selective pressures and founder effect. These evolutionary processes have resulted in substantial genetic and phenotypic diversity amongst BTV strains in the field (Bonneau \& MacLachlan, 2004). For example, particular strains such as attenuated egg and/or cell-adapted modified-live virus vaccines (MLVs) and the current European strains of BTV-8 (wild type) can cross the placenta, resulting in the birth of offspring that may be virus positive and/or demonstrate severe developmental defects. On the other hand, some BTV strains are unable to do so (Desmecht et al., 2008; MacLachlan et al., 2000; Osburn, 1994; Savini et al., 2012; Vercauteren et al., 2008). The severity of clinical signs has further been suggested to be influenced by differences in the virulence of the virus, which varies in a strain specific manner, independently of virus serotype (Caporale et al., 2011).

Bluetongue virus is transmitted through the bites of Culicoides midges (Du Toit, 1944) and has historically been considered endemic in temperate and tropical regions between the latitudes of $40-50^{\circ} \mathrm{N}$ and $35^{\circ} \mathrm{S}$ (Gibbs \& Greiner, 1994). However, during the last decade of the $20^{\text {th }}$ century and first decade of the $21^{\text {st }}$ century, BTV has spread to latitudes far north of its traditional boundaries (Purse et al., 2005). Since 1998, several BTV serotypes (1, 2, 4, 6, 8, 9, 11 and 16) of both wild type and vaccine origin have been introduced into Europe, resulting in unprecedented genetic diversity amongst strains circulating on the continent (Saegerman et al., 2008). Bluetongue virus contains a genome that consists of ten segments of linear dsRNA. Due to this segmentation, the virus can exchange its genome segments in mammalian or insect cells that have been co-infected with more than one strain of the virus 
(Samal et al., 1987a; Samal et al., 1987b). Genetic reassortment can potentially generate reassortants that differ from parental strains in their phenotypic characteristics. Bluetongue virus reassortment has previously been associated with changes in serological properties (Cowley \& Gorman, 1989; Maia \& Osburn, 1993; Mertens et al., 1989), changes in plaque morphology (Shaw et al., 2013) and novel virulence properties in mice and ruminants (Waldvogel et al., 1987; Waldvogel et al., 1992a; Waldvogel et al., 1992b). Reassortment may also potentially generate strains that differ in transmissibility by the insect vector (Riegler, 2002). Several BTV reassortants have since 2002, been isolated from the field in Europe and included both wild-type/wild-type and wild-type/vaccine strain reassortants (Batten et al., 2008;Maanet al., 2010;Shaw et al., 2013). Multiple unique clinical manifestations of BT in sheep in Israel may also be associated with infections by reassortant strains, although this has not been confirmed under experimental conditions (Brenner et al., 2011).

The BTV genome encodes seven viral proteins (VP1-VP7) and five non-structural proteins (NS1, NS2, NS3/NS3a, and NS4) (Belhouchet et al., 2011; Ratinier et al., 2011; Van Dijk \& Huismans, 1988). The mature virion is non-enveloped and composed of a triple layered icosahedral protein capsid, consisting of a sub-core (VP3, encoded by Seg-3), a core surface layer (VP7, encoded by Seg-7), and an outer protein layer (VP2 and VP5, encoded by Seg-2 and Seg-6, respectively). The sub-core encloses the ten genome segments as well as multiple copies of three enzymatic proteins (Gouet et al., 1999; Grimes et al., 1998; Hewat et al., 1992); VP1 (RNA-dependent RNA polymerase, encoded by Seg-1) (Boyce et al., 2004), VP4 (capping and trans-methylase enzyme, encoded by Seg-4) (Ramadevi et al., 1998) and VP6 (RNA-dependent ATPase and helicase, encoded by Seg-9) (Stauber et al., 1997). Viral protein 7 is a ligand for the insect cell receptor and appears to be able to mediate the attachment and infection of insect cells by core particles (Basak et al., 1997; Xu et al., 1997). The outer capsid proteins are involved in the attachment (VP2) (Hassan \& Roy, 1999) and release (VP5) (Forzan et al., 2004; Hassan et al., 2001) of the virus into the cytoplasm of mammalian cells. The non-structural proteins play a role in regulating viral protein expression (NS1, encoded by Seg-5) (Boyce et al., 2012), morphogenesis (NS2 encoded by Seg-8) (Kar et al., 2007) and intracellular trafficking/release (NS3/NS3a, encoded by Seg-10) (Hyatt et al., 1993). The function of NS4 (encoded by an out-of-frame open reading frame within the VP6 frame) is currently unclear. This protein localises in the nucleolus of infected cells early in the infection cycle and appears to give a replication advantage to certain strains 
of BTV in interferon treated mammalian cells. NS4 may therefore play a role in the evasion of host cell anti-viral defence mechanisms (Belhouchet et al., 2011; Ratinier et al., 2011).

Only limited studies have been conducted to investigate the effect of reassortment on BTV phenotype. The potential consequences of reassortment in regards to the course and epidemiology of the disease therefore remain uncertain. An incomplete understanding of the molecular determinants that influence BTV virulence and transmissibility further complicates this issue (reviewed by Coetzee et al., 2012). The generation of reassortants of BTV by coinfection of different in vitro and in vivo systems (forward genetics) has been described (Oberst et al., 1987; Ramig et al., 1989; Samal et al., 1987a; Samal et al., 1987b; Shaw et al., 2013). In addition, a reverse genetics system for BTV has recently been developed (Boyce et al., 2008). The latter technology allows the de novo generation of desired reassortants that can be used to study the phenotype of BTV in a specific manner. In the case of reverse genetics, in vivo studies have indicated that some phenotypic characteristics of rescued strains remains preserved (i.e. virulence and ability to cross the placenta), highlighting the suitability of this approach to generate viruses that can be used as models for BTV virulence and pathogenicity studies (Rasmussen et al., 2013; Van Gennip et al., 2012b).

The objective of the present study was to compare different phenotypic properties of selected reverse genetics parental and reassortant strains of BTV serotype 1,6 and 8 in mammalian cell culture, in order to examine whether reassortment can affect the in vitro phenotype of the virus. Selected in vitro parameters may reflect differences in virulence and transmissibility of BTV in vivo. In this study parental and reassortant strains were compared in regards to their virus replication kinetics, their rate of induction of CPE, the effects of viral infection on cell viability and the degree of induction of different mechanisms of cell death (apoptosis/necrosis).

\section{Materials and methods}

\subsection{Viruses}

The BTV reverse genetic strains/reassortants used in this study were previously described by van Gennip et al. (Van Gennip et al., 2010; Van Gennip et al., 2012). Briefly, BTVs and BTV reassortants were generated by transfecting BSR cells (a BHK-21 sub-clone) with 
capped T7 RNA transcripts derived in vitro from cloned cDNA's of BTV serotype 1, 6 and 8 or by using a targeted single genome segment modification strategy (Van Gennip et al., 2010; Van Gennip et al., 2012) (Table 1). The consensus sequences of genome segments have been submitted to Genbank [BTV-1 (FJ9697191- FJ9697281), BTV-6 (QG506472-QG506481) and BTV-8 (GQ506451-GQ506460)] of the National Centre for Biotechnology (NCBI, (http://www.ncbi.nlm.nih.gov/). The strains were selected for this study due to their availability from previous studies; the fact that the viruses were reassortants of attenuated and virulent strains, and that the parental strains had been evaluated for their virulence in ruminants.

The reverse genetics strain of BTV-1 ( $\mathrm{rgP} 1)$ is genetically closely related to the South African reference strain of BTV-1 (RSArrr/01) and to the MLV strain of serotype 1 produced by Onderstepoort Biological Products (OBP). Experimental infection of sheep with rgP1 has demonstrated that the virus is avirulent and only induces a few days of increased body temperature and a very low and transient viraemia in sheep (Dr. Piet van Rijn, personal communication). The rgP6 strain is derived from a BTV-6 field strain that was isolated in the Netherlands in 2008 (BTV6/net08). Segment-1 to Seg-9 shows 99.7-100\% nucleotide sequence identity to the South African BTV-6 MLV strain. Segment-10 (NS3/NS3a) of BTV6/net08 is however highly similar (98.4\%) to the South African BTV-2 MLV strain (Maan et al., 2008; Van Gennip et al., 2012b). Previous studies have demonstrated that BTV6/net08 and rgP6 are avirulent, and cause only mild/inapparent infections in sheep and cattle (Eschbaumer et al., 2009; Van Gennip et al., 2012b; Van Rijn et al., 2012). The parental rgP8 strain is based on consensus sequences of BTV-8/net07/01 (collection nr of The Pirbright Institute), a cattle isolate of BTV-8 from 2007 in the Netherlands. Both the reverse genetics and ancestral virus are virulent in experimentally infected sheep and cattle and can cause significant morbidity and mortality (Van Gennip et al., 2012b). Both rgP6 and rgP8 contain silent mutations that are spread across different genome segments with respect to the BTV6/net08 and BTV-8/net07/01 consensus sequences. These mutations were incorporated during construction of the rescue plasmids, and allow the viruses to be distinguished from the cognate field strains.

Two additional strains were included as controls. These included BTV8/net07/01 and the original BTV-6 MLV of Onderstepoort Biological Products (OBP, Pretoria, South Africa). The BTV-6 MLV strain was originally isolated from the field in South Africa and attenuated 
by sequentially passaging the virus in embryonated chicken eggs and cell culture (60x embryonated chicken egg passages, 3x plaque purifications, 7x passages on BHK cells).

\subsection{Virus characterization}

Before commencing experimental work, whole genome sequencing of the selected viral strains was conducted using Ion Torrent sequencing (ABI Life Sciences) in order to confirm the identity and constellation of BTV genome segments. "FLAC amplification" (full-length amplification of cDNAs) of each of the viral genomes was conducted as previously described (Potgieter et al., 2009). The preparation of DNA libraries, emulsion PCR and unidirectional sequencing on the Ion Torrent system (314/316 chip) was performed according to the manufacturer's instructions. Fastq files containing the sequence data and quality values were imported into the CLC genomics software (V5.5, http://www.clcbio.com/) and quality trimmed using default settings. Sequence reads were assembled with the CLC software by either mapping reads to reference sequences of BTV that were downloaded from the National Centre for Biotechnology (NCBI, (http://www.ncbi.nlm.nih.gov/) website or assembled using shotgun assembly (de novo) as appropriate, using default parameters. Consensus and/or contig sequences (>500 nt. in length) were subjected to a multi-nucleotide BLASTn (Basic Local Alignment Search Tool) at NCBI, in order to determine the sequence identities. In general sequencing yielded nearly full length sequences for each of the genome segments. All viruses further demonstrated $99-100 \%$ nucleotide sequence identity to the corresponding genome segments of the parental strains available on Genbank (results not shown).

\subsection{Reassortant virus nomenclature}

The nomenclature of the BTV strains in the present study (Table 1) is similar to that described by Meiring et al., (2009). The names are preceded by the prefix "rgP" or "rgR" to indicate parental and reassortant strains derived by reverse genetics. Thus, rgR6-8(10) indicates a BTV reassortant based on rgP6 with Seg-10 of rgP8.

\subsection{Cell culture}

All experiments were carried out using Vero cells (African green monkey kidney cells, American Type Culture Collection, Manassa, USA). Vero cells were propagated in 
Dulbecco's minimal essential medium (DMEM) containing 5\% gamma-irradiated foetal calf serum (FCS, Highveld Biological, South Africa), 10\% tryptose phosphate broth (v/v) and 1 $\mathrm{mg} / \mathrm{L}$ gentamycin and incubated at $37^{\circ} \mathrm{C}$ in an atmosphere containing $5 \% \mathrm{CO}_{2}$ and $98 \%$ humidity until $100 \%$ confluent. In order to prepare virus stocks, virus was passaged $3 \mathrm{x}$ on Vero cells until complete CPE was observed. The virus was released by $1 \mathrm{x}$ freeze/thawing, clarified by centrifugation at 2,000 $\mathrm{x}$ g for 20 minutes and immediately titrated in triplicate on Vero cells (Kärber, 1931). Working stocks were diluted to $3 \log _{10} \mathrm{TCID}_{50} / \mathrm{mL}$ in supplemented DMEM prior to conducting each assay. Pilot studies were conducted using viruses of different titres (up to $3 \log _{10} \mathrm{TCID}_{50}$ ) (results not shown) and a dose of $100 \mathrm{TCID}_{50}$ ( $0.01 \mathrm{~mL}$ of stock virus) selected. Using this dose, CPE is normally observed within 3-4 days post infection (dpi) in cell cultures in 96 well cell culture plates. All assays were performed in confluent cell monolayers in either 16 (E-plates) or 96-well cell culture plates (total volume $0.28 \mathrm{~mL}$ ). In order to prepare Vero monolayers, wells in cell culture plates were seeded with 38400 cells and left to equilibrate for 24 hours prior to viral infection. The assays were done in triplicate and readings averaged between replicates for each virus. The assays were in addition repeated on different days using different stock viruses in order to confirm particular data trends (representative data presented in Table 1 and Figures 1-4). Cell free medium and/or mock infected controls were included in the different assays as appropriate.

\subsection{Virus replication kinetics}

In order to generate virus growth curves, cell monolayers in 96-well plates were infected with virus (100 TCID 50 ), harvested at 24, 48, 72 and 96 hours post infection (hpi) and cell culture supernatant collected and titrated as previously described. Individual cell culture plates were frozen and thawed $3 \mathrm{x}$ times prior to titration, to facilitate virus release from infected cells into the cell culture medium.

\subsection{Cytopathic effect}

The onset and extent of CPEs were recorded in Vero cultures infected with each of the strains by continuously measuring the development of CPE using an electrical impedance assay (RTCA-DP system, xCELLigence, ACEA Biosciences) (Spiegel, 2009). Cell monolayers in 16-well E-plates were infected with virus at 24 hours post seeding and cell index (CI) values measured every 30 minutes over a 7-10 day period using the RTCA-DP system. Cell index 
values were averaged across replicates and normalised to the approximate time of virus addition (23.3-24.0 hpi). The time to a 50\% reduction in cell index value $\left(\mathrm{CI}_{50}\right)$ was subsequently determined. The $\mathrm{CI}_{50}$ value or $\mathrm{CPE}$ induction rate was defined as the time point at which the CI value had decreased to $50 \%$ of the maximum for each of the normalized CPE curves.

\subsection{Cell viability and mechanism of cell death}

In order to measure the ability of the viruses to cause cell death, a cell viability/necrosis/apoptosis assay (ApoTox $-\mathrm{Glo}^{\mathrm{TM}}$ Triplex Assay, Promega, catalog nr. TM322) was conducted in Vero cultures. Confluent monolayers in 96-well (black) plates were infected at 24 hours post seeding $\left(100\right.$ TCID $\left._{50}\right)$ and cellular markers for cell viability, apoptosis and necrosis measured at $72 \mathrm{hpi}$, according to the manufacturers' instructions, using a luminometer (i.e. bioluminescence and/or fluorescence; Glomax, Promega).

\subsection{Correlation between in vitro phenotypic properties}

A Spearman's rank correlation (Rho) test was used to examine the correlation between the in vitro parameters that were measured in this study, using mean data values (Corder and Foreman, 2009). An online Rho calculator was utilized to calculate $\mathbf{r}_{\mathbf{s}}$ and probability values (p) for pair-wise comparisons of the phenotypic parameters (http://www.socscistatistics.com /tests/spearman/Default2.aspx). The results were interpreted at the $95 \%$ significance level $(\mathrm{P}<0.05)$. Calculated $\mathrm{r}_{\mathrm{s}}$ and probability $(\mathrm{p})$ values for each pair-wise comparison are presented in Table 2.

\section{Results}

\subsection{Virus replication kinetics}

An evaluation of the virus replication kinetics of parental, reassortant and control strains indicated an increase in viral titre between 24-96 hpi. Differences in virus titres were observed between 24-72 hpi, and maximum titres recorded at $96 \mathrm{hpi}$ for most strains. Consequently, strains were compared at this sampling point (Figure 1 and Table 1). At 96 hpi, rgP6 yielded the lowest titre $\left(3.9 \log _{10} \mathrm{TCID}_{50} / \mathrm{mL}, \mathrm{SD} \pm 0.1\right)$. The $\operatorname{rgP} 1$ and $\operatorname{rgP} 8$ strains 
in contrast yielded higher titres of $6.3 \log _{10} \mathrm{TCID}_{50} / \mathrm{mL}(\mathrm{SD} \pm 0.1)$ and $5.2 \log _{10} \mathrm{TCID}_{50} / \mathrm{mL}$ $(\mathrm{SD} \pm 0.2)$, respectively. The wild-type BTV-8 strain (BTV8/net07/01) replicated to a titre of $5.9 \log _{10} \mathrm{TCID}_{50} / \mathrm{mL}(\mathrm{SD} \pm 0.4)$ whereas the BTV-6 MLV strain replicated to $4.8 \log _{10}$ $\mathrm{TCID}_{50} / \mathrm{mL}(\mathrm{SD} \pm 0.3)$.

Reassortants of $\mathrm{rgP} 1$ and $\mathrm{rgP} 6$ replicated to titres that appeared to correspond to either one or the other parental strain. The rgR1-6(1,3,4,8,9) and rgP1 strains demonstrated similar titres $\left(5.8 \log _{10} \mathrm{TCID}_{50} / \mathrm{mL}, \mathrm{SD} \pm 0.1\right.$ and $6.3 \log _{10} \mathrm{TCID}_{50} / \mathrm{mL}, \mathrm{SD} \pm 0.1$, respectively), whereas rgP6 and rgR1-6(2,6,7,10) in comparison replicated to similar $\left(3.9 \log _{10} \mathrm{TCID}_{50} / \mathrm{mL}, \mathrm{SD} \pm\right.$ 0.1 and $4.0 \log _{10} \mathrm{TCID}_{50} / \mathrm{mL}, \mathrm{SD} \pm 0.4$, respectively) but lower titres. The $\mathrm{rgP} 1 / \mathrm{rgP} 8$ reassortants, replicated to titres that appeared to be similar to both parental strains. Some variation was measured between $\mathrm{rgP} 1 / \mathrm{rgP} 8$ reassortants, that ranged from $5.7(\mathrm{SD} \pm 0.4)$ to $6.8 \log _{10} \mathrm{TCID}_{50} / \mathrm{mL}$ (SD $\left.\pm 0-0.4\right)$. The reassortant $\operatorname{rgR} 8-6(9,10)\left(5.9 \log _{10} \mathrm{TCID}_{50} / \mathrm{mL}, \mathrm{SD} \pm\right.$ $0.1)$ demonstrated a similar titre as $\operatorname{rgP} 8\left(5.2 \log _{10} \mathrm{TCID}_{50} / \mathrm{mL}, \mathrm{SD} \pm 0.3\right)$, whereas rgR68(10) (4.1 $\left.\log _{10} \mathrm{TCID}_{50} / \mathrm{mL}, \mathrm{SD} \pm 0.6\right)$, replicated to a similar titre as $\operatorname{rgP6}\left(3.9 \log _{10}\right.$ $\mathrm{TCID}_{50} / \mathrm{mL}, \mathrm{SD} \pm 0.1$.

\subsection{Cytopathic effects}

The development of CPE was measured by using an electrical impedance assay (xCELLigence, Roche). The assay measures changes in trans-monolayer electrical resistance in response to cellular morphological changes in the whole cell culture monolayer. The method was therefore suitable to measure the course of CPE induction and replace subjective visual scoring by microscopy. The results of the electrical impedance assay are expressed as $\mathrm{CI}_{50}$ values in Figure 2 (A to D) and Table 1. In general, infected cells continued to grow for at least 10 to 15 hours similar to mock-infected cells, after which CI values started to decline. Eventually, all viruses caused complete CPE that was confirmed by a CI value of zero.

The rates of CPE induction of the different strains are expressed as $\mathrm{CI}_{50}$ values in hours post infection (hpi). Parental reverse genetics strains (Figure 2A) showed individual CPE induction rates. Virulent strain rgP8 caused $\mathrm{CPE}$ the quickest $\left(\mathrm{CI}_{50}=64.5, \mathrm{SD} \pm 4.1\right)$. Avirulent strain $\operatorname{rgP} 6$ was the slowest $\left(\mathrm{CI}_{50}=98.0, \mathrm{SD} \pm 5.8\right)$, whereas the other avirulent strain $\mathrm{rgP} 1$ had an intermediate $\mathrm{CI}_{50}$ value of $71 \mathrm{hpi}(\mathrm{SD} \pm 4.7)$. The South African BTV-6 MLV strain and the field isolate of BTV-8 (BTV8/net07/01) showed similar CPE induction 
rates as the $\mathrm{rgP} 6$ and $\mathrm{rgP} 8$ strains, respectively (BTV-6 $\mathrm{MLV}, \mathrm{CI}_{50}=91, \mathrm{~S} \mathrm{D} \pm 5.8$; $\left.\mathrm{BTV} 8 / \mathrm{net} 07 / 01, \mathrm{CI}_{50}=61.0, \mathrm{SD} \pm 3.5\right)$.

CPE induction rates of $\operatorname{rgR} 1-6(1,3,4,8,9)$ and $\operatorname{rgR} 1-6(2,6,7,10)$ differed from the parental strains (Figure 2B). Strain rgR1-6(1,3,4,8,9) induced CPE faster $\left(\mathrm{CI}_{50}=68, \mathrm{SD} \pm 1.3\right)$ than $\operatorname{rgP} 1\left(\mathrm{CI}_{50}=71.0, \mathrm{SD} \pm 4.7\right)$, whereas $\operatorname{rgR} 1-6(2,6,7,10)$ was delayed $\left(\mathrm{CI}_{50}=142.5, \mathrm{SD} \pm 17.9\right)$ as compared to $\operatorname{rgP} 6\left(\mathrm{CI}_{50}=98, \mathrm{SD} \pm 5.8\right)$.

For the rgP1 and rgP8 reassortant strains (Figure 2C), the CPE induction rates appeared to be similar to that of $\operatorname{rgP} 8\left(\mathrm{CI}_{50}=64.5, \mathrm{SD} \pm 4.1\right)$ and distinct from that of $\operatorname{rgP} 1\left(\mathrm{CI}_{50}=71.0, \mathrm{SD}\right.$ \pm 4.7). Notably several reassortants [rgR1-8(5,8), $\operatorname{rgR} 1-8(2,5,8), \operatorname{rgR} 1-8(5,6,8), \operatorname{rgR} 1-$ $8(5,8,10),\left(\mathrm{CI}_{50}=48.0, \mathrm{SD} \pm 2.4\right.$ to $\left.62.0, \mathrm{SD} \pm 7.0\right)$ showed faster $\mathrm{CPE}$ induction rates as compared to $\operatorname{rgP} 8\left(\mathrm{CI}_{50}=64.5, \mathrm{SD} \pm 4.1\right)$.

The reassortants $\operatorname{rgR} 8-6(9,10)$ and $\operatorname{rgR} 6-8(10)$ demonstrated CPE induction rates that appeared distinct from both parental strains (Figure 2D). The strain $\operatorname{rgR} 8-6(9,10)\left(\mathrm{CI}_{50}=\right.$ 49.0, $\mathrm{SD} \pm 3.5)$ induced $\mathrm{CPE}$ faster than $\operatorname{rgP} 6\left(\mathrm{CI}_{50}=98.0, \mathrm{SD} \pm 5.8\right)$, which was closer to that demonstrated by $\operatorname{rgP} 8\left(\mathrm{CI}_{50}=64.5, \mathrm{SD} \pm 4.1\right)$. The $\operatorname{rgR6}-8(10)$ strain in turn demonstrated delayed $\mathrm{CPE}$ induction $\left(\mathrm{CI}_{50}=112.0, \mathrm{SD} \pm 8.1\right)$ relative to $\operatorname{rgP6}\left(\mathrm{CI}_{50}=98.0\right.$, $\mathrm{SD} \pm 5.8)$.

In summary, the CPE induction rates of the reassortant strains as measured by the electrical impedance assay and expressed as $\mathrm{CI}_{50}$ values, appeared to be different from that of the parental strains in several cases. Certain reassortants showed either increased or decreased CPE induction rates with respect to the parental strains, whereas some reassortants showed $\mathrm{CI}_{50}$ values close to that of one of the parental strains.

\subsection{Cell viability and mechanism of cell death}

The results of the viability assay indicated that most of the studied strains reduced the viability of infected cell cultures at 72 hpi with $50-80 \%$ compared to mock-infected controls (Figure 3 and Table 1). The few exceptions were rgR1-6(1,3,4,8,9), rgR1-6(2,6,7,10) and rgR6-8(10), which demonstrated smaller decreases. The last two strains demonstrated an 
approximate decrease of 20-30\%, whereas rgR1-6(1,3,4,8,9) demonstrated a decrease of 40$50 \%$.

The results from the necrosis/apoptosis assay indicated that visible CPE was associated both with necrotic and apoptotic cell death at 72 hpi (Figure 4 and Table 1). The strains varied widely in the extent of induced necrotic and apoptotic cell death. For the cytotoxicity assay, this varied from a 2-12 times increase in cytotoxicity, whereas for apoptotic cell death this varied from 2-17 times increase, relative to mock-infected controls. In particular rgR1$6(2,6,7,10)$ demonstrated low levels of both apoptosis and necrosis.

\subsection{Correlation between in vitro phenotypic properties}

Calculated Spearman correlation coefficients $\left(r_{s}\right)$ and probability $(p)$ values (Table 2) for a pair-wise comparison of the in vitro phenotypic properties, indicated a statistically significant positive correlation between the mean titre of virus at $96 \mathrm{hpi}$ and extent of apoptosis at $72 \mathrm{hpi}$ $\left.\left[\mathrm{r}_{\mathrm{s}}=0.701, \mathrm{p}(0.011)<0.05\right)\right]$; a statistically significant positive correlation between CPE induction rate $\left(\mathrm{CI}_{50}\right)$ and the percentage of cell viability remaining at $72 \mathrm{hpi}\left[\mathrm{r}_{\mathrm{s}}=0.874, \mathrm{p}\right.$ $(0.005)<0.0002]$ : a statistically significant negative correlation between CPE induction rate and extent of apoptosis at $72 \mathrm{hpi}\left[\mathrm{r}_{\mathrm{s}}=-0.748, \mathrm{p}(0.005)<0.05\right]$ and a statistically significant negative correlation between the percentage of cell viability remaining and extent of apoptosis at 72 hpi $\left[r_{s}=-0.699, p(0.005)<0.05\right]$. Statistically significant correlations could not be identified for the remaining comparisons.

\section{Discussion}

The objective of this study was to evaluate and compare selected in vitro properties of reverse genetics parental and reassortant (as well as control) strains of BTV-1, 6 and 8 in Vero cell cultures, in order to evaluate whether genetic reassortment could potentially affect the in vitro phenotype of the virus. In order to evaluate the effects of BTV reassortment, the test strains were compared in Vero cell culture in regards to selected phenotypic parameters. These parameters included an evaluation of viral replication kinetics, the rate with which the viruses induced CPE, the effect of viral infection on cell viability and the ability of the viruses to induce different mechanisms of cell death (apoptosis/necrosis). The choice of parameters was based on studies that have previously been documented with viruses from other genera, in 
which similar parameters were investigated as potential indicators of potential changes in in vivo virulence (Baumgartner et al., 1991; DeMaula et al., 2001; Freistadt \& Eberle, 1996; Slosaris et al., 1989; Tscherne \& Garcia-Sastre, 2011; Dortmans et al., 2011). Differences in viral replication kinetics in vitro - and by implication possible differences in the ruminant host - was further considered to be of interest, due to its potential influence on the level of viraemia, and by implication the efficiency of the virus' uptake by the insect vector during blood feeding (Veronesi et al., 2010).

The results from the in vitro study supported the notion that reassortment could potentially affect the phenotype of the virus, with reassortment appearing to be associated with changes in at least some of the phenotypic properties that were evaluated in this study. However, there was in general a lack of correlation between the measured parameters (with the exception of the rate of CPE induction) and previously documented differences in parental strain virulence in ruminants. For example, at 96 hpi the avirulent rgP1 was able to replicate to a higher titre $\left(6.3 \log _{10} \mathrm{TCID}_{50} / \mathrm{mL}, \mathrm{SD} \pm 0.2\right)$ in cell culture than avirulent $\operatorname{rgP} 6\left[3.9 \log _{10} \mathrm{TCID}_{50} / \mathrm{mL}, \mathrm{SD}\right.$ $\pm 0.1)$, whereas the $\mathrm{rgP} 1$ titre was more similar to that of virulent $\operatorname{rgP} 8\left(5.2 \log _{10} \mathrm{TCID}_{50} / \mathrm{mL}\right.$, $\mathrm{SD} \pm 0.2)$ ). All three parental strains further demonstrated a similar reduction in infected cell viability at $72 \mathrm{hpi}(30.7 \% \pm 5.2$ to $43.2 \% \pm 3.5)$. No overall pattern was discernable in regards to the documented virulence of the parental strains in vivo and extent of either cytotoxicity or necrosis at $72 \mathrm{hpi}$. Overall, this lack of correlation could be explained by general limitations in the applicability of in vitro models to the in vivo situation. The clinical manifestation of BT in the ruminant host, is a multi-factorial phenomenon that is thought to be influenced not only by intrinsic differences in the phenotype of BTV strains, but also by external host, vector and environmental factors that cannot be duplicated in cell culture (DeMaula et al., 2001; Foster et al., 1991; MacLachlan et al., 2009). In vitro conditions further differ from in vivo conditions in that cells are clonally derived and some cell types such as for example Vero cells as was used in this study, lack accompanying antiviral defences such as the interferon response and/or even specific viral receptor sites.

Despite the limitation of in vitro models in regards to their applicability to the in vivo situation, it was of interest to speculate whether particular phenotypic changes observed in cell cultures for the reassortant strains, may be reflected in in vivo changes in either transmissibility and/or virulence. For example, it was observed that some wild-type/MLV reassortants replicated to high titres, [(e.g. $\operatorname{rgR} 1-6(1,3,4,8,9)$ and $\operatorname{rgR} 8-6(9,10)$ replicated to 
$\left.>5 \log _{10} \mathrm{TCID}_{50} / \mathrm{mL}, \mathrm{SD} \pm 0.1\right)$ ], despite containing genome segments from the slow replicating rgP6 strain $\left(3.9 \log _{10} \mathrm{TCID}_{50} / \mathrm{mL}, \mathrm{SD} \pm 0.1\right)$. The replication of reassortant strains composed of genome segments from slow and fast replicating parental strains to high titres in vitro, as was observed in this study, may imply that these strains and therewith their genome segments may spread more efficiently in the field (e.g. either by influencing the peak level and/or duration of infectious viraemia). The possibility of MLV reassortment in this regard is particularly disconcerting as one specific goal of attenuation of BTV strains is to reduce the level of viraemia after vaccination of the ruminant host to a maximum titre of $3 \log _{10} \mathrm{TCID}_{50} /$ $\mathrm{mL}$ in blood (OIE, 2008). The titre has been proposed as a threshold with respect to onward transmission of the virus by Culicoides species (Savini et al., 2008). Additional in vivo studies should be conducted, to assess whether reassortment can alter the duration and level of viraemia in the ruminant host and whether such changes may be reflected in altered transmissibility of reassortant strains by Culicoides vectors.

An investigation of viral $\mathrm{CPE}$ induction rates indicated that the $\mathrm{CI}_{50}$ values for the parental strains corresponded partially to documented differences in virulence of the parental strains in ruminants. Thus, it was observed that the virulent strain $\operatorname{rgP} 8$ and control strain BTV-8 demonstrated faster CPE induction rates than attenuated strains of rgP1, rgP6 and the BTV-6 MLV vaccine strains, respectively. Changes in CPE induction rates were further observed for nearly every reassortant type analysed. For rgP1/rgP6 reassortants, reassortment appeared to be associated both with increased [rgR1-6(1,3,4,8,9)] and decreased CPE induction rates [rgR1-6(2,6,7,10)] (Figure 2B and Table 1). The rgP1/rgP8 reassortants in turn which contained two or three genome segments from rgP8 [i.e. $\operatorname{rgR} 1-8(5,8), \operatorname{rgR} 1-8(2,5,8), \operatorname{rgR} 1-$ $8(5,6,8), \operatorname{rgR} 1-8(5,7,8), \operatorname{rgR} 1-8(5,8,10)]$ demonstrated increased CPE induction rates as compared to rgP1 (Figure 2C and Table 1). In the case of rgP6/rgP8 reassortants, rgR6-8(10) showed a delayed CPE induction compared to both parental strains, whereas the reassortant rgR8-6(9,10) showed a similar CPE induction rate as rgP8 (Figure 2D, Table 1). Thus genetic reassortment between parental strains with distinct CPE induction rates resulted in variable and somewhat unpredictable CPE induction rates for the reassortant strains. Altered CPE induction rates for some reassortant strains could potentially reflect changes in the rate with which these strains may cause tissue damage in vivo, and may thus potentially reflect altered virulence. Additional studies in either mice and/or ruminants should be conducted, in order to clarify whether there is a correlation between $\mathrm{CPE}$ induction rate and in vivo virulence of the virus. 
Both necrosis and apoptosis have been demonstrated to play a role in BTV pathogenicity in vivo (DeMaula et al., 2001; Umeshappa et al., 2010). It was therefore of interest to evaluate whether the effect of viral infection on cell viability and/or induction of necrosis and apoptosis differed in cell cultures that were infected with the parental and reassortant strains. The Apotox Triplex assay results indicated that the effects of viral infection on cell viability, as well as the extent of necrosis and apoptosis induction varied widely between cell cultures that were infected with the different parental and reassortant strains. However in general a clear correlation and/or overall pattern between the parental and reassortant strains could not be observed. Nevertheless, the assay provided useful data in order to evaluate the relationship between the different in vitro phenotypic properties. The strong positive correlation $\left[r_{\mathrm{s}}=\right.$ $0.701, \mathrm{p}(0.0111)<0.05]$ that was observed between viral yield at 96 hpi and extent of apoptosis induction at $72 \mathrm{hpi}$, was interpreted as reflecting widespread damage to the cell culture monolayer as a result of apoptosis, and associated virus release at 72-96 hpi. Secondly, the strong positive correlation $\left[r_{s}=0.874, p(0.0002)<0.05\right]$ that was observed between the CPE induction rate and percentage of cell viability remaining at $72 \mathrm{hpi}$, was interpreted to reflect widespread morphological changes and associated cell death for highly cytopathic strains and vice versa for less cytopathic strains. This result suggests that the appearance of CPE is closely correlated to cell death. Thirdly, the strong negative correlation $\left[r_{\mathrm{s}}=-0.748 \mathrm{p}(0.0051)<0.05\right]$ that was observed between the CPE induction rate and extent of apoptosis induction at $72 \mathrm{hpi}$, suggests that increased rates of CPE induction was associated with increased levels of apoptosis induction for highly cytopathic strains and vice versa for less cytopathic strains. It therefore appears that the development of CPE is closely associated with cell death due to apoptosis. Finally, the strong negative correlation $\left[r_{\mathrm{s}}=-\right.$ $0.699, \mathrm{p}(0.8798)<0.05]$ that was observed between the percentage of cell viability remaining and extent of apoptosis induction at $72 \mathrm{hpi}$, suggests that apoptosis was the dominant mechanism of cell death in contrast to necrosis (cytotoxicity), for which a statistically significant correlation with cell viability could not be identified.

Bluetongue virus has been reported to be able to induce apoptosis in a wide range of mammalian cells cultures including Vero cells though uncoating of the VP2 and VP5 outer capsid proteins during the infection/fusion process (DeMaula et al., 2001;Mortola et al., 2004; Nagaleekar et al., 2007). It has further been shown that the degree of apoptosis induction varies in endothelial cells from different anatomical regions from ovine and bovine, and that the dominant mechanism of cell death is influenced by the presence of pro- 
inflammatory cytokines such as IL-1 and TNF- $\alpha$ (DeMaula et al., 2001). In this study, evidence was obtained that apoptosis was the dominant mechanism of cell death instead of necrosis. This is in agreement with finding of DeMaula et al., (2001), where endothelial cells that were infected with non-purified cell culture grown BTV (as was done in this study) primarily die due to apoptosis, due to the presence of pro-apoptotic mediators in the cell culture medium. A correlation was observed between the rate of CPE induction, the percentage of cell viability remaining at $72 \mathrm{hpi}$, and the extent of apoptosis induction in infected cell cultures in this study. Furthermore, these properties appear to vary between parental and reassortant strains. Concerning differences in in vitro phenotype that were identified between the parental and reassortant strains in this study, similar results have been reported by Shaw et al., (2013) for selected in vitro phenotypic properties (i.e. replication kinetics and plaque morphology) for BTV-1 and BTV-8 reassortant strains. The results are also in accordance with studies that have been conducted with African horse sickness virus (AHSV) reassortants in Vero cell cultures, where reassortants demonstrate differences in their viral replication kinetics, the extent with which the strains are able to induce CPE, and the extent with which reassortants are able to permeabilize the cell membrane (cytotoxicity) (Meiring et al., 2009).

The results from the study emphasise the potential, sometimes unpredictable consequences of reassortment between avirulent and virulent BTV strains. Apparently, reassortants with different constellations originating from parental strains with different phenotypic characteristics will not necessarily have intermediate in vitro characteristics. In general, it was not possible to correlate the exchange of any particular genome segment to phenotypic changes of parental strains in vitro, as the majority of reassortants were composed of multiple heterologous genome segments from both parental strains. Due to the difficulty with assigning phenotypic properties to particular genome segments when using multireassortants, it is recommended that future studies specifically focus on utilizing monoreassortants. Nevertheless, an examination of genome segment constellations in this study suggested that variation in several of the genome segments and/or encoded proteins may have been associated with changes in BTV phenotype (e g. VP2, VP5, NS1, NS2 and NS3/NS3a). These genomes segments have previously been implicated as potentially being associated with changes in virulence of either BTV or the closely related AHSV in vivo (Caporale et al., 2011; Huismans \& Howell, 1973; Meiring et al., 2009; O'Hara et al., 1998; Owens et al., 2004). In this study, only a small number of BTV reassortants that contained specific genome 
constellations were studied. These viruses were generated using reverse genetics under in vitro (i.e. artificial) conditions. Such specific viral constellations are therefore unlikely to emerge in the field. Nevertheless the study of the phenotypic characteristics of reassortant strains generated either by forward and/or reverse genetics, represents a first step in order to begin to understand the potential consequences of BTV reassortment.

Overall, this work raises questions in regards to the potential risk of reassortment between circulating MLVs and/or wild-type viruses in the field. Bluetongue virus MLV strains could contain several unfavourable phenotypic characteristics, not necessarily encountered in wildtype strains (e.g. inadequate attenuation, ability to cross the ruminant placenta and/or increased transmissibility) (Kirkland et al., 2004). These traits may be transferred from one strain to another during the reassortment process. Although evidence for the transfer of specific phenotypic traits due to reassortment is lacking, the potential of reassortment to transfer viral properties between different strains was considered important by animal health investigators in Europe during the 2006-2008 BTV-8 outbreak. Indeed, it was initially speculated that the ability of the European strain of BTV-8 to cross the placenta was acquired through reassortment with an MLV and/or unknown wildtype strain that demonstrated this ability (Brenner et al., 2011). Reassortment also poses a risk in regards to the use of disabled infectious single cycle vaccines in the field. Disabled infectious single cycle (DISC) vaccines are virus strains that contain deletions in essential regions of the viral genome, preventing replication of the virus in the ruminant host. However, the use of these strains in the field may still result in reassortment. An approach that has been suggested to overcome this problem involves the alteration of the virus genome using a sub-optimal codon approach, thereby reducing the competitive advantage of DISC strains and/or their genome segments in the field (Roy et al., 2009).

The advent of next generation sequencing technologies and genome characterisation of BTV field isolates will doubtless lead to the isolation of many more BTV reassortants from the field in future. This necessitates additional studies to identify the molecular determinants of BTV that influence viral phenotype, as well as studies to investigate the potential effect of reassortment of particular genome segments. The recent development of reverse genetics system through which mono-reassortants can be generated in a precise manner (Boyce et al., 2008), will facilitate such studies in future. In summary the present study contributes to previous findings that genetic reassortment between different BTV parental strains, may 
result in the generation of reassortant strains with altered phenotypic properties, at least in under in vitro conditions. Additional "parallel" in vivo and in vitro studies with the parental and reassortant strains should be conducted, in order to assess the implications of the results from this study in vivo.

\section{Competing interests}

The author(s) declare that they have no competing interests.

\section{Acknowledgements and funding}

The project was financially supported by the Norwegian State Educational Loan Fund (Lånekassen), Tine Dairy Cooperative (Norway), Animalia Meat and Poultry Research Centre (Norway), the IRT (Genomics) working group of the University of Pretoria, and the Ministry of Economic Affairs (CVI-project 1691022500), The Netherlands. The authors would like to express their gratitude to Ms. K. Ebersohn and Dr. C. Potgieter for technical assistance. We would also like to thank the Department of Biochemistry, University of Pretoria (South Africa) for permission to use their RTCA-DP (16 well x 3) system.

\section{References}

Basak, A. K., Grimes, J. M., Gouet, P., Roy, P. \& Stuart, D. I., (1997). Structures of orbivirus VP7: implications for the role of this protein in the viral life cycle. Structure 5, 871-883.

Batten, C. A., Maan, S., Shaw, A. E., Maan, N. S. \& Mertens, P. P., (2008). A European field strain of bluetongue virus derived from two parental vaccine strains by genome segment reassortment. Virus Res 137, 56-63.

Belhouchet, M., Mohd, J. F., Firth, A. E., Grimes, J. M., Mertens, P. P. \& Attoui, H., (2011). Detection of a fourth orbivirus non-structural protein. PLoS One 6, e25697.

Bonneau, K. R. \& MacLachlan, N. J., (2004). Genetic diversification of field strains of bluetongue virus. Vet Ital 40, 446-447.

Boyce, M., Celma, C. C. \& Roy, P., (2008). Development of reverse genetics systems for bluetongue virus: recovery of infectious virus from synthetic RNA transcripts. J Virol 82, 8339-8348.

Boyce, M., Celma, C. C. \& Roy, P., (2012). Bluetongue virus non-structural protein 1 is a positive regulator of viral protein synthesis. Virol. J. 9, 178.

Boyce, M., Wehrfritz, J., Noad, R. \& Roy, P., (2004). Purified recombinant bluetongue virus VP1 exhibits RNA replicase activity. $J$ Virol 78, 3994-4002. 
Brenner, J., Batten, C., Yadin, H., Bumbarov, V., Friedgut, O., Rotenberg, D., Golender, N. \& Oura, C., (2011). Clinical syndromes associated with the circulation of multiple serotypes of bluetongue virus in dairy cattle in Israel. Vet $\operatorname{Rec} 9$ (15), 389.

Caporale, M., Wash, R., Pini, A., Savini, G., Franchi, P., Golder, M., Patterson-Kane, J., Mertens, P., Di Gialleonardo, L., Armillotta, G., Lelli, R., Kellam, P. \& Palmarini, M., (2011). Determinants of bluetongue virus virulence in murine models of disease. J Virol 85, 11479-11489.

Coetzee, P., van Vuuren, M., Stokstad, M., Myrmel, M. \& Venter, E. H., (2012). Bluetongue virus genetic and phenotypic diversity: towards identifying the molecular determinants that influence virulence and transmission potential. Vet Microbiol 161, 1-12.

Corder, G. W. \& Foreman, D. I., (2009). Nonparametric Statistics for non-statisticians: A Step-by-Step Approach. Hoboken, N.J.: Wiley. ISBN 978-0-470-4546-19. OCLC 276228975.

Cowley, J. A. \& Gorman, B. M., (1989). Cross-neutralization of genetic reassortants of bluetongue virus serotypes 20 and 21. Vet Microbiol 19, 37-51.

DeMaula, C. D., Jutila, M. A., Wilson, D. W. \& MacLachlan, N. J., (2001). Infection kinetics, prostacyclin release and cytokine-mediated modulation of the mechanism of cell death during bluetongue virus infection of cultured ovine and bovine pulmonary artery and lung microvascular endothelial cells. $J$ Gen Virol 82, 787-794.

Desmecht, D., Bergh, R. V., Sartelet, A., Leclerc, M., Mignot, C., Misse, F., Sudraud, C., Berthemin, S., Jolly, S., Mousset, B., Linden, A., Coignoul, F. \& Cassart, D., (2008). Evidence for transplacental transmission of the current wild-type strain of bluetongue virus serotype 8 in cattle. Vet Rec 163, 50-52.

Dortmans, J. C., Koch, G., Rottier, P. J. \& Peeters, B. P., (2011). Virulence of Newcastle disease virus: what is known so far? Vet Res 42, 122.

Du Toit, R. M., (1944). The transmission of bluetongue and horsesickness by Culicoides. Onderstepoort Journal of Veterinary Science and Animal Industry 19, 7-16.

Eschbaumer, M., Hoffmann, B., Moss, A., Savini, G., Leone, A., Konig, P., Zemke, J., Conraths, F. \& Beer, M., (2009). Emergence of bluetongue virus serotype 6 in Europe-German field data and experimental infection of cattle. Vet Microbiol. 143 (2-4):189-195.

Forzan, M., Wirblich, C. \& Roy, P., (2004). A capsid protein of nonenveloped bluetongue virus exhibits membrane fusion activity. Proc Natl Acad Sci U S A 101, 2100-2105.

Freistadt, M. S. \& Eberle, K. E., (1996). Correlation between poliovirus type 1 Mahoney replication in blood cells and neurovirulence. J Virol 70, 6486-6492.

Gibbs, E. P. \& Greiner, E. C., (1994). The epidemiology of bluetongue. Comp Immunol Microbiol Infect Dis 17, 207-220.

Hassan, S. S. \& Roy, P., (1999). Expression and functional characterization of bluetongue virus VP2 protein: role in cell entry. $J$ Virol 73, 9832-9842.

Huismans, H. \& Howell, P. G., (1973). Molecular hybridization studies on the relationships between different serotypes of bluetongue virus and on the difference between the virulent and attenuated strains of the same serotype. Onderstepoort J Vet Res 40, 93-103.

Hyatt, A. D., Zhao, Y. \& Roy, P., (1993). Release of bluetongue virus-like particles from insect cells is mediated by BTV nonstructural protein NS3/NS3A. Virology 193, 592-603.

Kar, A. K., Bhattacharya, B. \& Roy, P., (2007). Bluetongue virus RNA binding protein NS2 is a modulator of viral replication and assembly. BMC Mol Biol 8, 4. 
Kärber, G., (1931). Beitrazurkovecktiven Behandlungpharmakologischer Reihenversucbe. Archiv der Experimentellen und Pathologischen Pharmakologie 162, 480-483.

Kirkland, P. \& Hawkes, R. A., (2004). A comparison of laboratory and 'wild' strains of bluetongue virus - is there any difference and does it matter? Vet Ital 40, 448-455.

Maan, S., Maan, N. S., Nomikou, K., Veronesi, E., Bachanek-Bankowska, K., Belaganahalli, M. N., Attoui, H. \& Mertens, P. P., (2011). Complete genome characterisation of a novel 26th bluetongue virus serotype from Kuwait. PLoS One 6, e26147.

Maan, S., Maan, N. S., van Rijn, P. A., van Gennip, R. G., Sanders, A., Wright, I. M., Batten, C., Hoffmann, B., Eschbaumer, M., Oura, C. A., Potgieter, A. C., Nomikou, K. \& Mertens, P. P., (2010). Full genome characterisation of bluetongue virus serotype 6 from the Netherlands 2008 and comparison to other field and vaccine strains. PLoS One 5, e10323.

MacLachlan, N. J., Conley, A. J. \& Kennedy, P. C., (2000). Bluetongue and equine viral arteritis viruses as models of virus-induced fetal injury and abortion. Anim Reprod Sci 60-61, 643-651.

MacLachlan, N. J., Crafford, J. E., Vernau, W., Gardner, I. A., Goddard, A., Guthrie, A. J. \& Venter, E. H., (2008). Experimental reproduction of severe bluetongue in sheep. Vet Pathol 45, 310-315.

MacLachlan, N. J., Drew, C. P., Darpel, K. E. \& Worwa, G., (2009). The pathology and pathogenesis of bluetongue. J Comp Pathol 141, 1-16.

Martin, L. A., Meyer, A. J., O'Hara, R. S., Fu, H., Mellor, P. S., Knowles, N. J. \& Mertens, P. P., (1998). Phylogenetic analysis of African horse sickness virus segment 10: sequence variation, virulence characteristics and cell exit. Arch Virol Suppl 14, 281-293.

Meiring, T. L., Huismans, H. \& van Staden, V. (2009). Genome segment reassortment identifies nonstructural protein NS3 as a key protein in African horsesickness virus release and alteration of membrane permeability. Arch Virol 154, 263-271.

Mertens, P. P., Pedley, S., Cowley, J., Burroughs, J. N., Corteyn, A. H., Jeggo, M. H., Jennings, D. M. \& Gorman, B. M., (1989). Analysis of the roles of bluetongue virus outer capsid proteins VP2 and VP5 in determination of virus serotype. Virology 170, 561-565.

OIE (2004). OIE Manual for Diagnostic Tests and Vaccines.

Owens, R. J., Limn, C. \& Roy, P., (2004). Role of an arbovirus nonstructural protein in cellular pathogenesis and virus release. $J$ Virol 78, 6649-6656.

Potgieter, A. C., Page, N. A., Liebenberg, J., Wright, I. M., Landt, O. \& van Dijk, A. A., (2009). Improved strategies for sequence-independent amplification and sequencing of viral double-stranded RNA genomes. J Gen Virol 90, 1423-1432.

Purse, B. V., Mellor, P. S., Rogers, D. J., Samuel, A. R., Mertens, P. P. \& Baylis, M., (2005). Climate change and the recent emergence of bluetongue in Europe. Nat Rev Microbiol 3, 171-181.

Ramadevi, N., Burroughs, N. J., Mertens, P. P., Jones, I. M. \& Roy, P., (1998). Capping and methylation of mRNA by purified recombinant VP4 protein of bluetongue virus. Proc Natl Acad Sci U S A 95, 13537 13542 .

Ramig, R. F., Garrison, C., Chen, D. \& Bell-Robinson, D., (1989). Analysis of reassortment and superinfection during mixed infection of Vero cells with bluetongue virus serotypes 10 and 17. J Gen Virol 70, 2595-2603

Rasmussen, L. D., Savini, G., Lorusso, A., Bellacicco, A., Palmarini, M., Caporale, M., Rasmussen, T. B., Belsham, G. J. \& Botner, A., (2013). Transplacental transmission of field and rescued strains of BTV2 and BTV-8 in experimentally infected sheep. Vet Res 44, 75. 
Riegler, L. (2002).Variation in African horse sickness virus and its effect on the vector competence of Culicoides biting midges. p. http://epubs.surrey.ac.uk/843/: University of Surrey.

Roy, P., Boyce, M. \& Noad, R., (2009). Prospects for improved bluetongue vaccines. Nat Rev Microbiol 7, 120-128.

Saegerman, C., Berkvens, D. \& Mellor , P. S., (2008). Bluetongue Epidemiology in the European Union. Emerg Infect Dis 14, 539-544.

Samal, S. K., el-Hussein, A., Holbrook, F. R., Beaty, B. J. \& Ramig, R. F., (1987a). Mixed infection of Culicoides variipennis with bluetongue virus serotypes 10 and 17: evidence for high frequency reassortment in the vector. J Gen Virol 68, 2319-2329.

Samal, S. K., Livingston, C. W., Jr., McConnell, S. \& Ramig, R. F., (1987b). Analysis of mixed infection of sheep with bluetongue virus serotypes 10 and 17: evidence for genetic reassortment in the vertebrate host. J Virol 61, 1086-1091.

Savini, G., Maclachlan, N. J., Sanchez-Vizcaino, J. M. \& Zientara, S., (2008). Vaccines against bluetongue in Europe. Comp Immunol Microbiol Infect Dis 31, 101-120.

Shaw, A., Ratinier, M., Nunes, S. F., Nomikou, K., Caporale, M., Golder, M., Allan, K., Hamers, C., Hug, M., Zientara, S., Breard, E., Mertens, P. \& Palmarini, M. (2013). Reassortment between two serologically unrelated bluetongue virus strains is flexible and can involve any genome segment. $J$ Virol, 87(1), 543-57.

Slosaris, M., Levy, B., Katz, E., Levy, R. \& Zakay-Rones, Z., (1989). Elevated virulence of Newcastle disease virus strains following serial passages in kidney cells in vitro. Avian Dis 33, 248-253.

Spiegel, M., (2009). Real-time and dynamic monitoring of virus-mediated cytopathogenecity. Biochemica 3, 15-17.

Spreull, J., (1905). Malarial catarrhal fever (bluetongue) of sheep in South Africa. Journal of Comparative Pathology and Therapeutics 18, 321-337.

Stauber, N., Martinez-Costas, J., Sutton, G., Monastyrskaya, K. \& Roy, P., (1997). Bluetongue virus VP6 protein binds ATP and exhibits an RNA-dependent ATPase function and a helicase activity that catalyze the unwinding of double-stranded RNA substrates. J Virol 71, 7220-7226.

Tscherne, D. M. \& Garcia-Sastre, A., (2011). Virulence determinants of pandemic influenza viruses. J Clin Invest 121, 6-13.

Umeshappa, C. S., Singh, K. P., Nanjundappa, R. H. \& Pandey, A. B., (2010). Apoptosis and immunosuppression in sheep infected with bluetongue virus serotype-23. Vet Microbiol. 7(2):e30540 [doi:10.1016/j.vetmic.2010.02.033].

Van Dijk, A. A. \& Huismans, H., (1988). In vitro transcription and translation of bluetongue virus mRNA. $J$ Gen Virol 69, 573-581.

Van Gennip, R. G., van de Water, S. G., Potgieter, C. A., Wright, I., Veldman, D. \& van Rijn, P. A., (2012). Rescue of recent virulent and avirulent field strains of bluetongue virus by reverse genetics. PLoS One 7, e30540.

Van Gennip, R. G., Veldman, D., van de Water, S. G. \& van Rijn, P. A., (2010). - Genetic modification of bluetongue virus by uptake of "synthetic" genome segments. Virology Journal 7, 261.

Veronesi, E., Darpel, K. E., Hamblin, C., Carpenter, S., Takamatsu, H. H., Anthony, S. J., Elliott, H., Mertens, P. P. \& Mellor, P. S., (2010). Viraemia and clinical disease in Dorset Poll sheep following vaccination with live attenuated bluetongue virus vaccines serotypes 16 and 4. Vaccine 28, 1397-1403. 
Verwoerd, D. W. \& Erasmus, B. J. (2004). Bluetongue. In Infectious Diseases of Livestock. 2nd edition. Edited by Coetzer J.A.W and Tustin RC. Cape Town, South Africa: Oxford University Press;12011220 .

Waldvogel, A. S., Anderson, C. A., Higgins, R. J. \& Osburn, B. I., (1987). Neurovirulence of the UC-2 and UC-8 strains of bluetongue virus serotype 11 in newborn mice. Vet Pathol 24, 404-410.

Waldvogel, A. S., Anderson, G. A., Phillips, D. L. \& Osburn, B. I., (1992a). Association of virulent and avirulent strains of bluetongue virus serotype 11 with premature births of late-term bovine fetuses. $J$ Comp Pathol 106, 333-340.

Waldvogel, A. S., Anderson, G. A., Phillips, D. L. \& Osburn, B. I., (1992b). Infection of bovine fetuses at 120 days' gestation with virulent and avirulent strains of bluetongue virus serotype 11. Comp Immunol Microbiol Infect Dis 15, 53-63.

Worwa, G., Hilbe, M., Ehrensperger, F., Chaignat, V., Hofmann, M. A., Griot, C., Maclachlan, N. J. \& Thuer, B., (2009). Experimental transplacental infection of sheep with bluetongue virus serotype 8 . Vet Rec 164, 499-500.

Xu, G., Wilson, W., Mecham, J., Murphy, K., Zhou, E. M. \& Tabachnick, W., (1997). VP7: an attachment protein of bluetongue virus for cellular receptors in Culicoides variipennis. J Gen Virol 78, 1617-1623. 


\section{Tables}

Table 1: Summary of parental, control and reassortant strain phenotypic properties as measured using the various assays.

\begin{tabular}{|c|c|c|c|c|c|}
\hline Virus name & $\begin{array}{c}\text { Mean virus titre } \\
\left(\log _{10} \mathrm{TCID}_{50} / \mathrm{mL}\right) \\
\text { at } 96 \mathrm{hpi}\end{array}$ & Time to $\mathrm{CI}_{50}{ }^{a}$ & $\begin{array}{l}\text { Mean percentage cell } \\
\text { viability remaining at } \\
\qquad 72 \mathrm{hpi}^{b}\end{array}$ & $\begin{array}{c}\text { Mean increase in } \\
\text { cytotoxicity at } 72 \\
\text { hpi }^{b}\end{array}$ & $\begin{array}{l}\text { Mean increase in } \\
\text { apoptosis at } 72 \mathrm{hpi}^{b}\end{array}$ \\
\hline rgP1 & $6.3 \pm 0.1$ & $71.0 \pm 4.7$ & $43.2 \pm 3.5$ & $5 \pm 0.9$ & $14.6 \pm 0.9$ \\
\hline $\operatorname{rgP} 6$ & $3.9 \pm 0.1$ & $98.0 \pm 5.8$ & $33.8 \pm 8.9$ & $9.8 \pm 1.5$ & $12.3 \pm 0.7$ \\
\hline $\operatorname{rgP} 8$ & $5.2 \pm 0.2$ & $64.5 \pm 4.1$ & $30.7 \pm 5.2$ & $8.9 \pm 1.1$ & $11.4 \pm 1.2$ \\
\hline BTV-8 (BTV8/net07/01) & $5.9 \pm 0.4$ & $61.0 \pm 3.5$ & $28.2 \pm 0.1$ & $8.8 \pm 0.2$ & $9.6 \pm 2.2$ \\
\hline BTV-6 (MLV) & $4.8 \pm 0.3$ & $91.5 \pm 5.8$ & $23.7 \pm 1.4$ & $8.6 \pm 0.1$ & $12.8 \pm 2.0$ \\
\hline $\operatorname{rgR} 1-6(1,3,4,8,9)$ & $5.8 \pm 0.1$ & $68.0 \pm 1.3$ & $54.7 \pm 5.0$ & $11.6 \pm 0.3$ & $11.6 \pm 0.5$ \\
\hline $\operatorname{rgR} 1-6(2,6,7,10)$ & $4.0 \pm 0.4$ & $142.5 \pm 17.9$ & $76.4 \pm 2.3$ & $1.2 \pm 0.8$ & $1.8 \pm 0.1$ \\
\hline $\operatorname{rgR} 1-8(5,8)$ & $6.3 \pm 0.3$ & $52.5 \pm 2.9$ & $27.1 \pm 6.5$ & $10 \pm 1.8$ & $17 \pm 0.5$ \\
\hline $\operatorname{rgR} 1-8(2,5,8)$ & $5.7 \pm 0.4$ & $48.0 \pm 2.4$ & $20.2 \pm 1.2$ & $7.6 \pm 0.4$ & $16.5 \pm 0.1$ \\
\hline $\operatorname{rgR} 1-8(5,6,8)$ & $6.3 \pm 0.0$ & $62.0 \pm 7.0$ & $21.2 \pm 1.4$ & $6.2 \pm 0.2$ & $16.2 \pm 0.4$ \\
\hline $\operatorname{rgR} 1-8(5,7,8)$ & $6.8 \pm 0.3$ & $64.0 \pm 3.5$ & $23.3 \pm 5.2$ & $5.9 \pm 0.2$ & $15.8 \pm 0.3$ \\
\hline $\operatorname{rgR} 1-8(5,8,10)$ & $6.3 \pm 0.0$ & $53.5 \pm 0.8$ & $20.0 \pm 2.1$ & $7.2 \pm 0.2$ & $13.4 \pm 0.2$ \\
\hline $\operatorname{rgR6}-8(10)$ & $4.1 \pm 0.6$ & $105.0 \pm 7.0$ & $76.1 \pm 2.6$ & $8.4 \pm 0.7$ & $4.4 \pm 0.3$ \\
\hline $\operatorname{rgR} 8-6(9,10)$ & $5.9 \pm 0.1$ & $50.5 \pm 4.1]$ & $21.7 \pm 1.2$ & $8.1 \pm 1.2$ & $13 \pm 1.2$ \\
\hline
\end{tabular}

${ }^{a}$ Cell index values were normalised at $23.3 \mathrm{hpi}$

${ }^{b}$ Cell viability, cytotoxicity and apoptosis data are presented as averaged values relative to mock infected controls. 
Table 2: Calculated Sprearman correlation $\left(\mathbf{r}_{\mathbf{s}}\right)$ coefficients and probability $(\mathbf{p})$ values that were generated for pair-wise comparisons of the in vitro properties/parameters (Table 1) in the present study. Mean values for each property were used to calculate the correlation coefficients. Probability values were interpreted at the $95 \%$ significance level $(\mathrm{p}<0.05)$. Probability values are indicated in brackets next to the $\mathrm{r}_{\mathrm{s}} \mathrm{values}$.

\begin{tabular}{ccccc}
\hline & CPE induction rate & Cell viability (72 hpi) & Cytotoxicity (72 hpi) & Apoptosis (72 hpi) \\
\hline Median titre at 96 hpi & $-0.523(0.0810)$ & $-0.537(0.0700)$ & $-0.278(0.3816)$ & $0.701(0.0111)$ \\
CPE induction rate & N/A & $0.874(0.0002)$ & $-0.133(0.6802)$ & $-0.748(0.0051)$ \\
Cell viability (72 hpi) & N/A & N/A & $0.084(0.7952)$ & $-0.699(0.0051)$ \\
Cytotoxicity (72 hpi) & N/A & N/A & $-0.049(0.8798)$ \\
\hline
\end{tabular}




\section{Figures}

Figure 1: Replication kinetics of parental, reassortant and control strains in Vero cell culture. Cell cultures in 96 well plates were infected with 100 TCID $_{50}$ of each of the test strains and supernatants collected at 24, 48, 72 and 96 hpi. Supernatants were immediately titered in Vero cells by limiting dilution analysis. Error bars indicate the standard deviations for replicate readings.

\section{Figure 2A}

\section{Figure 2B}

\section{Figure 2C}

\section{Figure 2D}

Figure 2: Cytopathic effect profiles and induction rates of parental, control and reassortant strains in Vero cell cultures. Sixteen well E-plates were seeded with 38400 Vero cells and left to equilibrate for 24 hours. Three wells each were subsequently infected with 100 TCID $_{50}$ of the test strains and CI values measured by using the RTCA-MP system every 30 minutes over a 7-10 day period. Cell index values were normalised at $23.28 \mathrm{hpi}$ and $\mathrm{CI}_{50}$ values calculated. Error bars on each composite curve indicate the standard deviations for individual CPE curves. Bluetongue virus strains are summarised in the different figures in relevant groupings (Figure 2A, parental and control strains; Figure 2B, BTV-1/6 strains/reassortants; Figure 2C, BTV-1/8 strains/reassortants; Figure 2D, BTV-6/8 strains/reassortants) and their corresponding $\mathrm{CI}_{50}$ values (and standard deviations) indicated below the individual figures. Note that $\mathrm{CI}_{50}$ values are given as averaged values for each composite curve. 
Figure 3: Effect of test strain infection $\left(100 \mathrm{TCID}_{50}\right)$ on Vero cell culture viability at $72 \mathrm{hpi}$. Cell viability values were measured by using the Apotox Triplex assay at $72 \mathrm{hpi}$. The data is presented as the average percentage of viability remaining relative to that of mock-infected controls. Each bar is composed of data generated from three independent replicates. Error bars indicate standard deviations for replicate readings.

Figure 4: Evaluation of the mechanism and degree of cell death induced by test strain infection (100 TCID 50 in Vero cells at 72 hpi. Cellular markers for apoptosis and necrosis were measured by using an Apotox Triplex assay. The results are presented as the average increase in apoptosis/necrosis relative to that of mock-infected controls. Each bar is composed of data that was generated from three independent replicates. Error bars indicate the standard deviations for replicate readings. Cytotoxicity values are indicated in blue and apoptosis in maroon. 


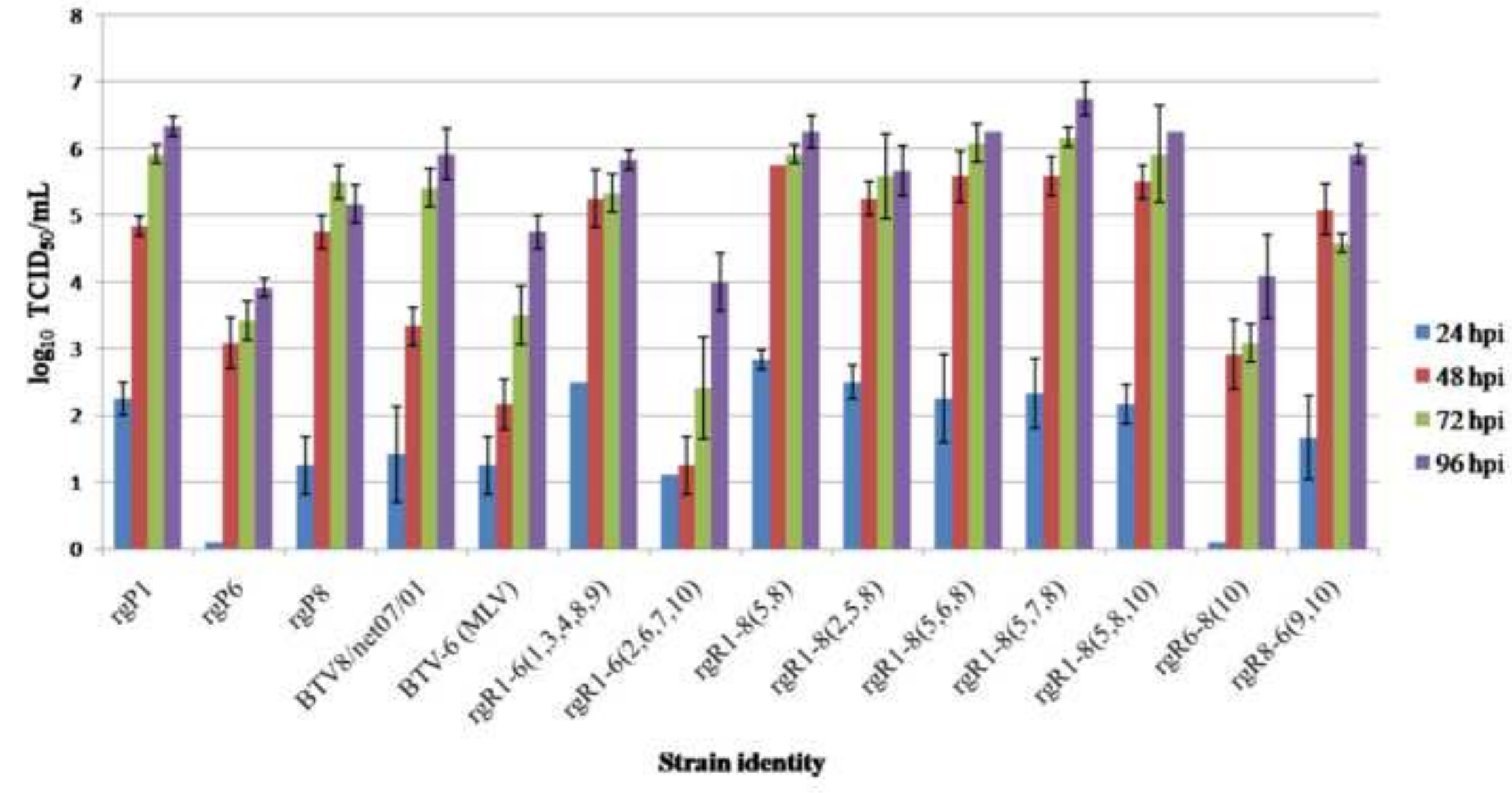




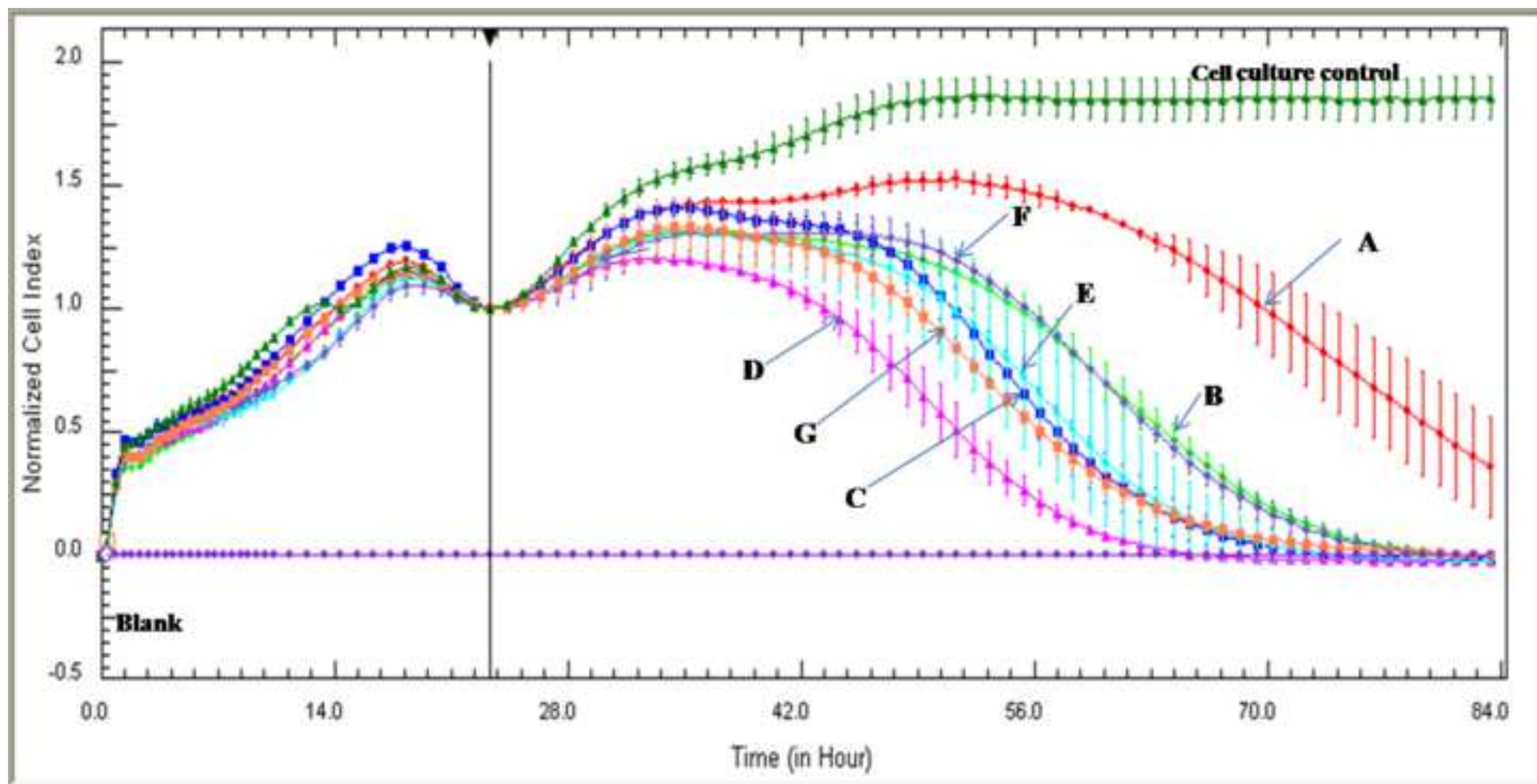

Curve identities and $\mathrm{CI}_{50}$ values for BTV-1 and BTV-8 strains/reassortants

A) $\mathrm{ggP1}[71.0 \pm 4.7]$

B) $\mathrm{rgPB}[64.5 \pm 4.1]$

C) $\mathrm{rgR} 1-8(5,8)[52.5 \pm 2.9]$

D) $\mathrm{rgR} 1-8(2,5,8)[48.0 \pm 2.4]$

E) $\operatorname{rgR} 1-8(5,6,8)[62.0 \pm 7.0]$

F) $\mathrm{rgR} 1-8(5,7,8)[64.0 \pm 3.5]$

G) $\mathrm{rgR} 1-8(5,8,10)[50.5 \pm 4.1]$ 


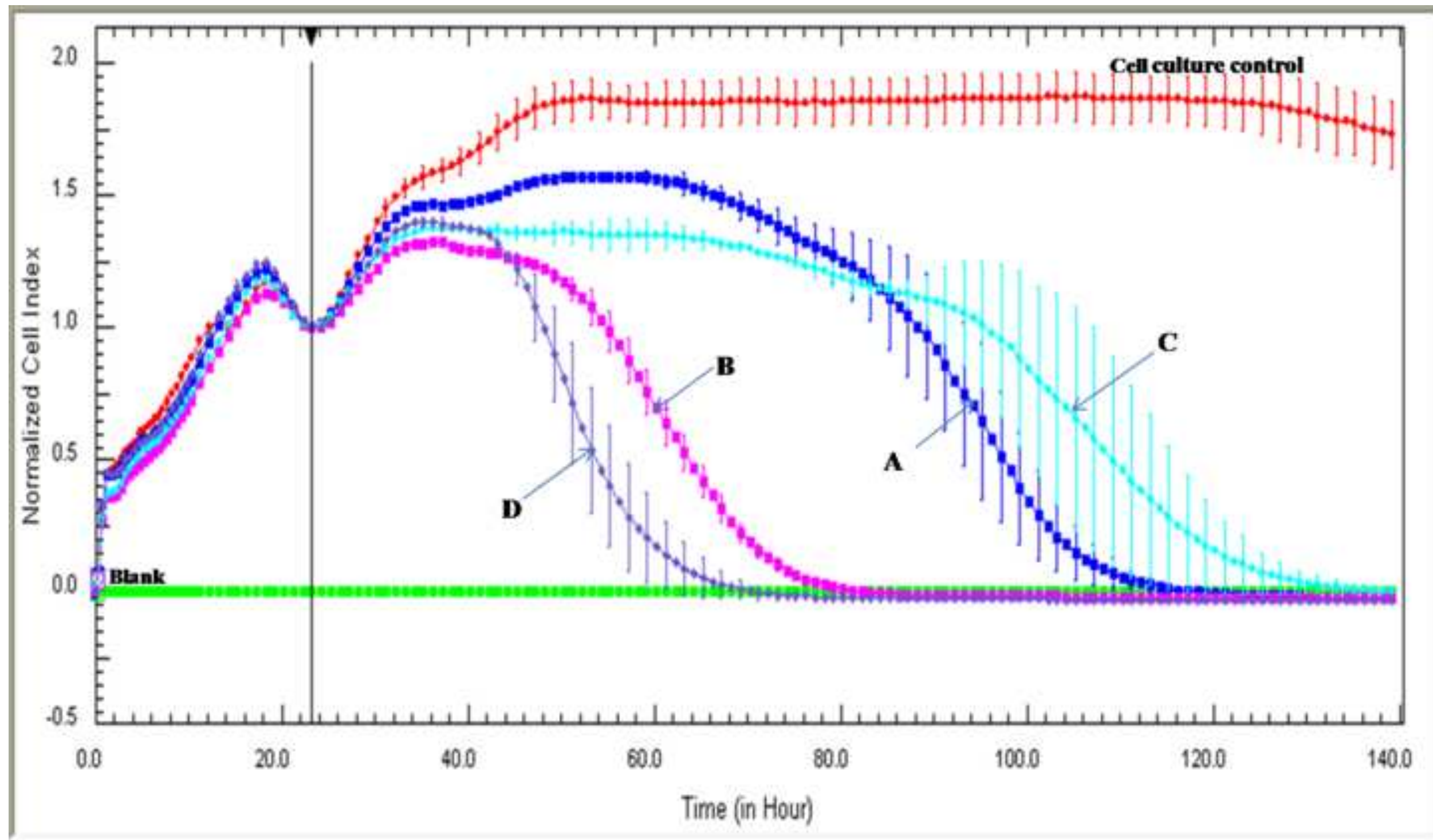

Curve identities and $\mathrm{CI}_{50}$ values for BTV -6 and BTV -8 strains/reassortants

A) rgP6 $[98.0 \pm 5.8]$

B) $\mathrm{rgPB}[64.5 \pm 4.1]$

C) rgR6-8(10) [112 48.1$]$

D) $\mathrm{rgR} 8-6(9,10)[19.0 \pm 3.5]$ 


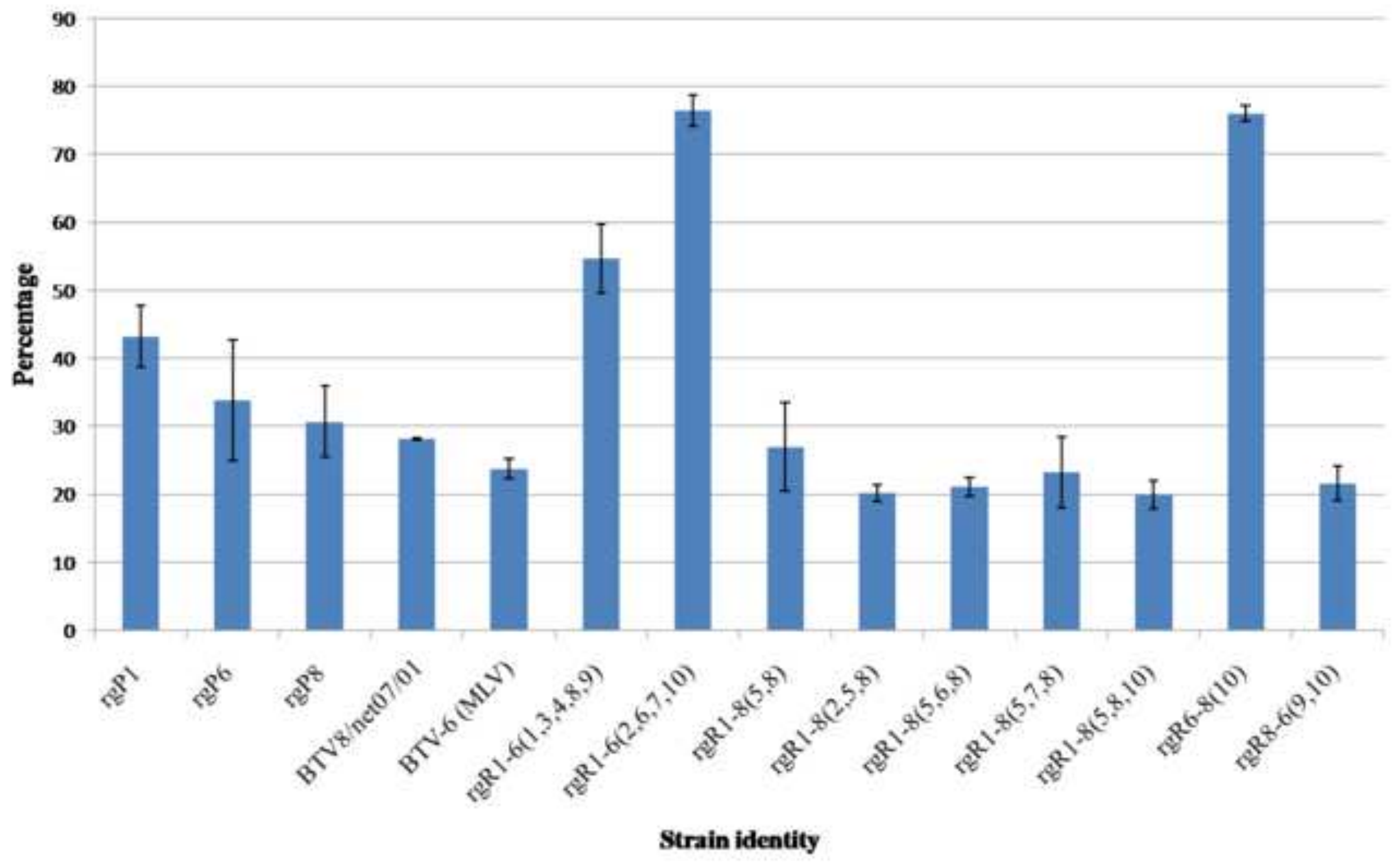




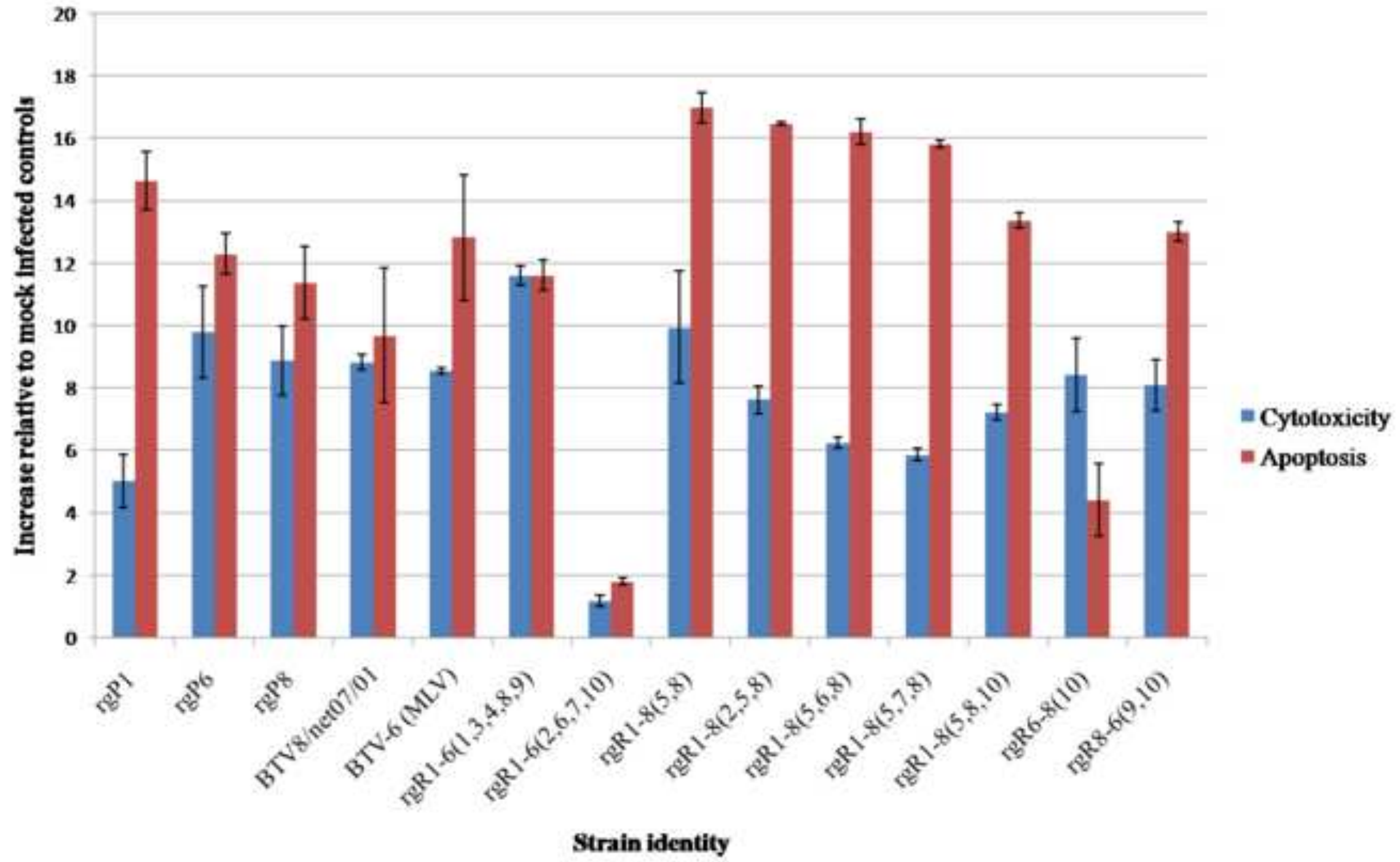

